\title{
LETAKEN 'OLAM: ARREGLAR EL MUNDO, UNA TAREA HUMANA' (Una perspectiva desde el judaísmo)
}

Letaken 'olam: arranging the world, a human task (A perspective from Judaism)

Ana María Tapia Adler

Centro de Estudios Judaicos

Universidad de Chile amtuch@u.uchile.cl

En el denominado Libro de los Libros ${ }^{2}$, respecto a la creación del hombre, está escrito:

Y creó Dios al hombre a su imagen, a imagen de Dios los creó: varón hembra los creó. (Génesis 1, 26-7)

Entonces Dios formó al hombre del polvo de la tierra, y sopló en su nariz aliento de vida, y fue el hombre un ser viviente.... (Génesis 2, 7)

El hombre fue creado por Dios a su imagen, conforme a su semejanza para que, como dice más adelante, señorease en los peces del mar, en las aves de los cielos, en las bestias, en toda la tierra, y en todo animal que se arrastra sobre la tierra.

Una lectura simple me permite apreciar que el hombre no es un descendiente de Dios pero tampoco es un producto de las fuerzas ciegas de la naturaleza. Al contrario, es un artefacto de Dios, creado a propósito y con un propósito. Fue creado con dos elementos: tierra y hálito divino que, combinados, conforman una unidad multifacética que hacen de ella un "nefesh ${ }^{3}$ jayá", una persona viva.

De allí puedo fácilmente desprender una primera enseñanza: que la humanidad es, -pese a su diversidad-, esencialmente una sola familia y que no hay diferencias que haga que un determinado pueblo, raza o religión sea mejor que otra.

\footnotetext{
${ }^{1}$ Presentado al Seminario Interdisciplinario de Religión y Cultura, $N^{\circ} 14$ (2008) p. 13-26

${ }^{2}$ Muchos denominan de ese modo al texto bíblico.

${ }^{3}$ Nefesh, término hebreo que designa a alma.
} 
Ese mundo fue planificado "divinamente" para ser una creación pacífica, armónica y comprensiva, donde el hombre -al igual que otros seres vivos- no debiera destruir a sus semejantes ni siquiera por necesidad de alimento.

Este ser distinto, fue creado con un propósito específico y fue colocado en una posición de excepción en el marco natural que define cada ser acorde a una estratificación simple y en orden ascendente: tierra, vegetales, animales, hombre. En esta estratificación toda frontera, excepto la humana, está claramente definida. El hombre es una criatura abierta y ese es el origen esencial de su libertad.

El león nace. La hormiga nace. El hombre, en cambio, se hace. Es cierto que en forma parcial nace, nace en cuanto cuerpo, materia, pero con esta materia prima hay que hacer algo: hacer un hombre, construir un destino, libre.

Pese a su importancia no fue creado en primer sino en último lugar, porque al decir de los sabios del judaísmo

"si es digno podrá considerar todo este mundo un palacio que se le preparó previamente y al cual ingresó cuando ya todo estaba listo. Pero si es indigno se le dice: hombre, no seas vanidoso. No eres nada, el mínimo insecto te precedió en la creación....".

Hay un salmo que siempre viene a mi mente cuando contemplo las maravillas de la naturaleza:

"Cuando veo los cielos que hicieron tus dedos la luna y las estrellas que Tú estableciste, me pregunto, ¿qué es el hombre para que lo recuerdes o el hijo del hombre para que lo tengas en cuenta?

Lo hiciste algo menor que Dios y lo rodeaste de gloria y belleza lo pusiste a gobernar Tus obras, todo dejaste bajo sus pies..." (Salmos 8: 3-6) 
El hombre, criatura que está entre el polvo y Dios y que ha sido puesto por responsable de las obras de Dios pertenece a una escala natural, proviene del reino animal, terrenal y es dentro de ese reino y ese mundo que ha de realizar su esencia. Sin embargo, este ser posee un aditamento muy especial, ha sido hecho a imagen y semejanza de Dios. Su función es conquistar, dominar, rasgos que no aparecen en la creación de los seres que le anteceden. En ninguna parte del texto puede desprenderse eso.

Volvamos a Génesis:

Y Dios tomó al hombre y lo colocó en el jardín del Edén, para que lo trabajase y lo cuidase”. (Génesis 2:15)

El Midrash respecto a este versículo, explica:

“Cuando el Todopoderoso Creó a Adán, lo llevó por el jardín del Edén: 'Mira mi obra' dijo El. 'Ve cuan hermosa es, cuan excelente. Lo creé todo por tu bien. Mira pues que no eches todo a perder y destruyas mi mundo, puesto que si lo haces, no habrá nadie que lo rehaga". (Midrash Kohelet Rabba, 7:28).

Todos los tipos de vida animal y vegetal, desde las bacterias a las algas y a los seres animados incluyendo al hombre, están ligados estrechamente entre sí y dependen unos de otros, así como del medio ambiente común. Todo cuanto interfiera en este delicado balance natural puede ocasionar efectos incalculables sobre todo el sistema, del que la vida humana forma parte.

"Y tomó el Eterno, Dios, al hombre y lo puso en el huerto del Edén para que lo labrara y para que lo guardara. Y encomendó el Eterno, Dios, al hombre diciendo: 'De todo árbol del huerto comerás. Y del árbol del saber del bien y del mal, no comerás de él, porque en el día de tu comer de él, morir morirás..."(Génesis 2, 15-17)

Adán y Eva vivían en el Jardín del Edén donde Dios les permitió comer de todo excepto de un árbol: el del conocimiento del bien y del mal. Eva falló, no resistió la tentación y no sólo comió del fruto sino que, además, persuadió a Adán para que lo hiciere. Por ese acto fueron castigados. 
La pregunta, obvia para mí, es ¿cómo puedo interpretar este texto y qué enseñanza extraigo de él?

Nuestros rabinos señalan que la enseñanza que subyace, en este texto es que la obediencia a las leyes de Dios es más importante que la adquisición del conocimiento. Porque al conocimiento de igual modo habríamos accedido, ya que Dios obsequió al hombre la mente y la razón.

Mente y razón fueron herramientas entregadas al hombre para que éste tomara conciencia y conociera la creación, el universo, su entorno. El hombre debía aprender a usarlas y entender cuál fue el propósito de estos obsequios y de qué modo debía usarlos.

Deduzco que es justamente cuando el hombre desconoce las leyes de Dios, sus enseñanzas y las sobrepasa o intenta hacerlo a través del conocimiento, cuando producimos sufrimiento y desgracias porque el producto de ese conocimiento es usado para destruir, para matar, para obtener mayor poder que los demás. Así, pues, el conocimiento no debe sobrepasar las leyes divinas, debe emplearse con responsabilidad compartiendo los beneficios que él pueda otorgar.

Siempre me pregunté si Adan y Eva fueron castigados sólo por el mero hecho de haber comido el fruto prohibido. ¡No! Sin temor a equivocarme, hoy puedo decir que nuestros míticos padres fueron castigados por lo que su actitud subyacía: el deseo de alcanzar el conocimiento por el conocimiento, desconociendo las leyes divinas. Más aún, lo fueron porque no supieron asumir la responsabilidad de sus actos:

Cuando Dios les llamó, se escondieron.

Responsabilidad implica compromiso, obligación, cumplimiento de su cometido, solidaridad. O como dijo Hillel: 
Ama a tu prójimo como a ti mismo, el resto es comentario: Ve y estudia” 5.(Vaikrá (lv)19:18)

Estudiar para practicar lo estudiado, para hacer de este el mundo al que debe conquistar no en el sentido de despojar, robar, capturar asaltar u oprimir, y al que se le conmina dominar pero en el sentido de servir, respetar, hacerse responsable por él.

¿Y qué tenemos en cambio? Locura, incomunicación, destrucción, falta de tiempo para compartir, para conversar. La rapidez de las comunicaciones nos sobrepasa, la rutina diaria y el trabajo en exceso consume nuestro tiempo y como bien se señala en Dr. Roa (1995) "la realidad deja de ser un valor de uso, cuyo descubrimiento, contemplación y manejo enriquece la vida de los hombres,(para convertirse) en valor de cambio, similar al dinero: vale en la medida que pueda ser cambiado por otra cosa". 6

Pareciera ser que el mundo ha enloquecido. Día a día los medios de comunicación masiva traen hasta nosotros noticias que hablan de violencia y muerte. Ellas llegan en el instante mismo en que se producen o con muy poca diferencia horaria. Así, desde un largo tiempo a esta parte nos hemos acostumbrado a que -diariamente- ingresen a la intimidad de nuestros hogares pavorosas escenas de guerra y destrucción que van desde la sofisticada Guerra del Golfo -con un aparataje bélico excepcional- pasando por los dramáticos sucesos de la ex Yugoslavia, la pavorosa situación de Ruanda, para concluir con múltiples atentados terroristas en diferentes partes del mundo, graffitis, amenazas varias, corrupción, y otros flagelos que azotan la humanidad entera.

Y me pregunto: ¿Qué nos está sucediendo? ¿Estamos perdiendo nuestra sensibilidad? ¿Qué estamos haciendo por aquellos que están siendo afectados? ¿Qué nos estamos haciendo a

\footnotetext{
${ }^{5}$ Vaikrá (levítico) 19:18 - Hilel enseñó que la Torá puede ser resumida en un único concepto abarcador.

${ }^{6}$ Armando Roa R., "Modernidad y Posmodernidad”Ed. Andrés Bello, Santiago, 1995. Capítulo III.

La Posmodernidad (Págs. 39 - 49). Preparado por Jaime Moreno para el curso Religión y posmodernidad, Departamento de Pregrado, cursos de formación general, Universidad de Chile.
} 
nosotros mismos? ¿Es este el mundo en el que debemos vivir? ¿Estamos a la altura de la misión que debemos cumplir? ¿Cuál es mi lugar en medio de todo esto?

Muchas son las interrogantes que me vienen a la mente y parecen surgir de lo más recóndito de mí. Las respuestas pueden ser variadas. Ellas van desde el cuestionarse uno mismo si con el exiguo poder que tenemos podemos hacer algo; enrostrar a los "grandes" que sí tienen como parar estas atrocidades y no lo hacen; reírnos de la ineficacia de las instituciones nacionales e internacionales, compadecernos por quienes sufren, o bien, dar vuelta la página del diario o cambiar de canal.

Para mí la respuesta es simple: El mundo -y yo soy parte de él- ha perdido su norte. Hay un silencio e inactividad culpables, cómplice, asistimos a la muerte de los ideales, a la pérdida de la sensibilidad, lo que es prueba palpable de la des-humanización de esta era tecnológica en la que vivimos.

Pareciéramos encajar perfectamente en esta era postmoderna porque los posmodernos -al decir de Armando Roa- no andan tras la trascendencia espiritual, la comunión con la naturaleza ni la búsqueda del reino milenario porque para ellos no vale la pena hacer ningún esfuerzo por conquistar nada difícil, por vivir con altura, por sufrir por nada ${ }^{7}$.

Ante lo que acontece en el mundo que nos rodea nos conmovemos, sí. Pero también desviamos el rostro para no ver lo que las imágenes nos muestran, mientras tomamos un rico café en el calor de nuestros hogares.

Olvidamos que en el texto bíblico se nos enseña que el hombre, a diferencia de los animales, no sólo vive su vida sino que la piensa, es capaz de preguntar y preguntarse acerca de su puesto en el mundo, de la misión que le compete, de la relación que debe establecer entre él y su medio, entre él y su prójimo, entre él y su Creador. Los primeros capítulos nos entregan una visión de mundo que desde el momento inicial de la creación del

\footnotetext{
${ }^{7}$ Idem.
} 
universo hasta la aparición del hombre, presentado como culminación del mismo y, luego, sigue con la reflexión sobre la condición humana.

El hombre es una criatura creada a imagen y semejanza de Dios, dotado de poder, inteligencia y libertad. Este hombre, para existir, depende del mundo material que precedió a su propia creación porque sin él, no habría podido sobrevivir, depende de las relaciones que construya con su prójimo y del sentido que le dé a su vida.

El hombre está capacitado para discernir entre distintas situaciones y tiene la facultad para optar, posee libre albedrío. Pero, ¿qué significa ser libre? ¿Poseer la facultad de desobedecer a Dios? Y si así fuere ¿por qué, entonces, fue castigado por no acatar su orden? Y... ¿por qué si la creación es buena existe el mal en el mundo?

Junto con esas preguntas primordiales, existenciales, inherentes al hombre de todos los tiempos surgen las respuestas que recurren a la desobediencia a la prohibición divina, o al no haberse hecho responsable de sus actos y por eso llega al mundo la muerte, el dolor, el desarraigo, el trabajo agotador y la sumisión de la mujer al varón (su marido) y el dolor en la crianza de los hijos.

El texto propone modelos de comportamiento que sirven para vivir en pareja, en familia, en sociedad. De los textos de Génesis 1:28 a y 2:24, se deduce que la cohabitación forma parte de los derechos y deberes del hombre y de la mujer, que el vínculo establecido entre ambos debe ser de mutua ayuda y compañía, tanto como para que el hombre abandone a sus padres y forme "una sola carne" con su compañera.

El sexo aparece como elemento natural, normal y fundamental de la vida humana. La bendición divina de la sexualidad se expresa en la procreación, en tener hijos. De ahí se sigue que el modelo deseable para el hombre es el disfrute de "la sola carne" como procreador y con progenie. En otras palabras, el modelo deseable es la familia. 
¿Qué pasó con este modelo de familia, de sexualidad sana, de modelo de familia? Matrimonios destrozados, niños abandonados, pedofilia, violencia intrafamiliar, homosexualidad.

\title{
¿Hombre dónde estás?
}

\author{
"Dios llamó al hombre, y le dijo: ¿Dónde estás tú? \\ ${ }^{10}$ Y él respondió: Oí tu voz en el huerto, y tuve miedo, porque estaba \\ desnudo; y me escondi". (Gen. 3:9-10)
}

\section{¿Hombre, cuál es el sentido de tu vida?}

Se cuenta que Víctor Frankl narra que "fue invitado a dictar una conferencia en la Universidad de Georgia acerca del tema “¿Está loca la nueva generación?” Durante el trayecto hacia la universidad comentó con el viejo taxista negro el tema de su conferencia. Para su sorpresa, el chofer soltó una sonora carcajada y le dijo. "Desde luego que están

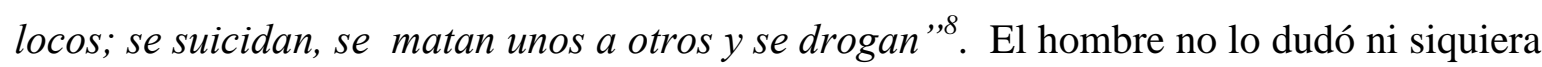
un instante y es más, se mostró muy extrañado de que invitasen a alguien desde lejos, a discutir un tema tan evidente".

Para el experimentado psicólogo, depresión, agresividad, uso de drogas es el moderno trío de fenómenos constituyentes de neurosis colectiva, que ha sido empíricamente demostrada por una investigación sobre 60 intentos de suicidio en la Universidad de Idaho. 85\% de los mismos dieron como razón "La vida no tiene sentido para mi" (life means nothing to me). Lo más curioso fue que el 93\% de los que contestaron así gozaban de buena salud, tenían

\footnotetext{
${ }^{8}$ Viktor Frankl y la frustración existencial en Rafael Guijarro Descubrir el sentido de la vida. http://www.mercaba.org/Filosofia/Frankl/viktor_frankl_y_la frustracion_e.htm
} 
una situación socioeconómica desahogada, satisfactorios expedientes académicos y no sufrían conflictos familiares. Estamos en presencia de la frustración existencial.

En un estudio realizado entre estudiantes vieneses este diagnóstico aumentó del 30.\% al $80 \%$ en menos de dos años. ¿Por qué aumentan las manifestaciones de neurosis? La respuesta parecería ser "sensación de inutilidad.

Para Freud, el origen de las neurosis era producido por frustraciones sexuales, para Alfred Adler el problema detonaba, básicamente, por el complejo de inferioridad.

Frankl señala que hoy debemos preocuparnos sobre todo de las frustraciones existenciales y en la sensación de inutilidad que ello implica para quien la sufre

Un estudiante norteamericano le escribió: "Tengo 22 años, soy licenciado, tengo un automóvil de lujo, no dependo económicamente de nadie y gozo de más prestigio y satisfacciones sexuales de las que necesito. No obstante, ¿qué sentido tiene todo esto?". 9

El escritor Nicolás Mosley, autor de la novela "Natalie" escribió en una de las páginas que nadie se atreve a hablar de la vida concediéndole algún sentido es una materia tabú como antes lo fuera la sexualidad.

El sentido de la vida, es el aspecto que diferencia al hombre de los demás animales. Ningún animal se interroga por el significado de su existencia: sabe por instinto qué cosas debe hacer. Sólo el hombre puede llegar a dudar hasta de que su vida tenga sentido.

Para Frankl el ser humano es el que se trasciende a sí mismo hacia algo distinto de sí, hacia algo o alguien a quien ser útil o a quien amar. Para él, un cierto desfase entre lo que se es y lo que se desea ser enriquece la personalidad.

${ }^{9}$ Idem 
Cuando se logra comprender esto, hasta el sufrimiento cobra sentido según se puede constatar de la experiencia personal de Víctor Frankl en Auschwitz y Dachau, que le obligó a descubrir que quienes tenían más posibilidades de sobrevivir eran los que deseaban vivir para desarrollar en el futuro la tarea que habían elegido.

¿Cuál es el sentido de mi vida? ¿Cuál es el sentido de sus vidas? No es algo que se pueda comprar ni heredar. Debe ser encontrado por cada uno por sí mismo y no se puede dar arbitrariamente.

Dice Frankl que "El significado es una forma objetiva sobre el fondo de la realidad, una posibilidad que se atisba y una necesidad". ${ }^{10}$ Una posibilidad única e irrepetible que permanece después de cada actuación. Las características de unicidad e irrepetibilidad permiten que cada vida tenga su propio sentido.

Lo que sí es transmisible son los significados universales, que se podrían definir como valores, pero el significado irrepetible debe ser comprendido por cada hombre singular. Por lo que el psicólogo hace una llamada a la conciencia personal que es para él el órgano que procura este significado.

Para una época como la que vivimos, en que desaparecen las tradiciones, con mayor razón la educación debe ser educación de la conciencia personal para no verse obligado a hacer lo que otros quieren (totalitarismo) o querer lo que otros hacen (conformismo) ${ }^{11}$.

Dice Frankl que la conciencia es la que permitirá encontrar al hombre de hoy, de mañana y del futuro, el significado de las situaciones a pesar de la desaparición de las tradiciones y de los valores transmitidos con ellas.

\section{Hombre, ¿Quién eres?}

\footnotetext{
${ }^{10}$ Idem

${ }^{11}$ Viktor E. Frankl: "La voluntad de sentido" en Aquilino Polaino-Lorente. En busca de un remedio al vacío existencial. http://www.mercaba.org/Filosofia/Frankl/viktor_frankl_y_la_frustracion_e.htm
} 
Ya lo dijimos, en esencia es la gran obra de Dios, creado con una concepción determinada y a quien Dios le dio el libre albedrío, y la libre elección:

- Si quiere se corrompe o si quiere se ennoblece

- Si quiere es bueno y si quiere es malo,

- Si quiere construye o destruye

- Si quiere mata o si quiere da vida.

Nadie puede detenerlo ¿radica allí su grandeza? Es posible que para algunos así sea y para otros no.

El hombre, dicen los sabios del judaísmo, era puro en su naturaleza, el bien y el mal estaban fuera de él, al comer del fruto prohibido los introdujo en sí y la lucha interior entre ambos elementos ¿sentimientos? le produjo confusión.

El hombre debió abandonar el paraíso y, al hacerlo, disminuyó su nivel espiritual a uno inferior. De allí que Dios le dijo: 'ahora tienes que comenzar un nuevo proyecto para poder recuperar tu estatus original'.

Ese proyecto, dicen, dura 6000 años y está compuesto por tres partes. 1- período del abismo; 2- período de la espiritualidad; 3 - período del fin del proyecto. Cada uno es un período de 2000 años.

Si nos adentramos en el Tanaj encontramos las profecías de Zacarías y de Iejezquiel. Acerca del fin de la historia. Zacarías habla de guerras, destrucción masiva, corrupción moral integral; nos habla de sangre y muerte. Y así se llegará al fin de los días, en el cual el hombre volverá a su estado original. En cambio, para Iejezquiel (Ezequiel), el hombre volverá a sus orígenes en un acontecimiento histórico de paz, armonía, unión y felicidad. 
¿Cómo puede ser que dos profetas que hablan sobre la misma situación, se contradigan tan abiertamente?

Pareciera ser simple, se refiere a que el proyecto se va a realizar "sí o sí". Pero el cómo dependerá enteramente de nosotros.

No hay que ser muy brillante para darse cuenta que la justicia social, los derechos humanos, la moralidad, la educación en valores, la salud para todos, etc., etc, están en la "agenda país" e incluso "agendas países", pero no es menos cierto que se quedan estancadas en papeles y documentos, no en el corazón y el hacer de los hombres.

Este doble standard es hipocresía pura, existe la posibilidad de hacer algo pero no se hace y, si en alguna parte se hiciera, es en menor escala. El profeta Iejezquiel plantea la necesidad de que el hombre varíe su comportamiento ya que sólo entonces 'los hijos harán volver el corazón de los padres'; de lo contrario se cumplirá lo que dijo Zacarías: el mundo va a volver a su estado original pero por un proceso de conflicto.

Así, pues, tenemos un grave problema: no sabemos, no somos capaces o no nos interesa encontrar nuestro objetivo. El mundo puede ir a su desaparición, pero no por intervención divina sino humana. El hombre está llevando al mundo a la destrucción.

\section{Hombre ¿Qué harás?}

Según la tradición judía, y supongo que en otras tradiciones religiosas también se lo cree, cada uno de nosotros tiene un contacto directo con Dios. No importa en qué actividad estemos: sentados escuchando una conferencia, paseando por una avenida, en el trabajo, en compañía de conocidos y amigos, Dios nos observa para ver nuestras reacciones, para ver si tomamos conciencia de cada acto, de cada palabra. Lo hace, supongo, para calibrar si cada acto está en el marco del proyecto que Él nos trazó.

Pareciera ser que, en la actualidad, hay dos propuestas. Y ellas dividen a las personas en dos gruposAquellos que se convierten en Iejezquiel o en Zacarías. Esto es o vuelven los valores trascendentes o siguen con los valores terrenales y mundanos.

Cuadernos Judaicos ISSN: 0718-8749

Volumen Aniversario 50 años 
Plantée preguntas en tercera persona, dirigidas al "hombre" genérico. La actitud correcta sería, primera persona singular: En este caso, las preguntas que podría hacerme un tanto temerosa son:

AnaMaría ¿Dónde estás?

AnaMaría, ¿Quién eres?

AnaMaría ¿cuál es el sentido de tu vida?

AnaMaría ¿Qué harás para cumplir tu proyecto?

Las respuestas son tal vez la clave de la esperanza:

Estoy aquí,

Soy yo, encerrada entre las circunstancias que rodean mi vida, mis fortalezas y debilidades.

Soy yo, que estoy aquí buscando, buceando, desmenuzando, escrutando, viviendo...

Hay quienes temen no poder cumplir su proyecto, no poder ser en esta vida quienes deben ser. Es el caso del rabino Zusia, que se preguntaba:

Cuando yo muera y me presente ante el Santo bendito sea, y El me pregunte: Zusia, Zusia, ¿por qué no fuiste Moisés? Yo sabré que responderle, si me pregunta Zusia, Zusia, por qué no fuiste Hillel, yo sabré qué contestar. Pero ¿y si me pregunta Zusia, Zusia, por qué no fuiste Zusia?, ¿Qué le habré de responder? ${ }^{12}$

Existen aquellos que se sientan a esperar un milagro, a rezar para adelantar la llegada del Mashiaj (Mesías) que vendrá a arreglar el desaguisado provocado por los hombres.

Un midrash ${ }^{13}$ cuenta que, a las puertas de la ciudad vieja de Jerusalem, de la puerta Jaffo, sobre un saliente rocoso, está sentado un individuo. Quienes por allí transitan

\footnotetext{
${ }^{12}$ Relato del Tesoro jasídico.

${ }^{13}$ Midrash, se refiere a un método de exégesis bíblica pero también a enseñanzas destinadas a clarificar, ejemplificar situaciones legales o de otro tipo, de donde surge todo un tipo de literatura midráshica con cuentos, parábolas, etc.
} 
habitualmente, lo ven siempre allí, sentado, silente, día y noche, primavera, invierno, otoño y verano. Hasta que un día, aguijoneado por la curiosidad, se acerca un transeúnte y le pregunta: Siempre te veo acá, no duermes, no comes, no te mueves puedes decirme ¿quién eres? El hombre levanta su cabeza, le mira directamente a los ojos y responde: Soy el Mesías. Sin dar crédito a sus oídos, tembloroso y tartamudeante, el hombre exclama:

¡¿Mesias?!, ¡el mesías!, mira como está el mundo, te estamos esperando, esperamos por ti, ¿qué estás esperando para actuar?

Sin desviar su mirada, el Mesías responde: Te estoy esperando a ti.” 